\title{
The impact of terrorism on the FDI of the EU and EEA Countries ${ }^{* 1}$
}

\author{
Heri Bezićn ${ }^{2}$ Tomislav Galovic ${ }^{3}$, Petar Miševic ${ }^{4}$
}

\begin{abstract}
The key goal of this research is to empirically determine the effects of terrorism on FDI of the selected EU and EEA member countries. The methodology is based on a system-GMM estimator for dynamic panel data models on a sample covering up to 29 countries, and 13-year periods from 2000 to 2013. The main results confirm that terrorism incidents, economic and institutional variables are found to depress FDI of analysed EU and EEA countries. It can be concluded that terrorism and institutional stability are most influential on FDI inflows of the observed EU and EEA countries. The results indicate that terrorist activities reduce security and confidence of investors in countries exposed to terrorist activities, reducing the inflow of foreign direct investment. The recommendations and proposals are given based on the results of empirical analysis.
\end{abstract}

Key words: terrorism, GMM estimator, FDI, EU, EEA

JEL classification: F52, F59, F21, F62

\footnotetext{
* Received: 23-09-2016; accepted: 09-12-2016

${ }^{1}$ Research has been fully supported by the University of Rijeka under the project number 13.02.1.3.13.

2 Full Professor, University of Rijeka, Faculty of Economics, Ivana Filipovića 4, 51000 Rijeka, Croatia. Scientific affiliation: technological policy and competitiveness, international business. Phone: + 38551355 148.E-mail: bezic@efri.hr.

${ }^{3}$ Assistant Professor, University of Rijeka, Faculty of Economics, Ivana Filipovića 4, 51000 Rijeka, Croatia. Scientific affiliation: technological policy and competitiveness, international business.Phone: + 38551355 155.E-mail:tgalovic@efri.hr.

4 PhD, Employed at Croatian Chamber of Commerce, Roosvelt Square 2, 10000 Zagreb, Croatia. E-mail:pmisevic@hgk.hr.
} 


\section{Introduction}

Due to its topicality, terrorism has been gaining in importance in the context of scientific and professional discussions. The events that occurred in the European Union in 2015 and 2016 (terrorist activities in France, Belgium, Germany, etc.) additionally underline the importance of the prevention of terrorism by strengthening national security and economic activities of the countries.

Terrorism is a violent act that has certain characteristics. It is primarily an act that carries a message that refers to the the objectives and intentions of the executor of the terrorist act. For this reason, after a terrorist attack, terrorists take responsibility for the terrorist act. Another important characteristic of terrorism is fear and causing fear. It is a desired effect in order to achieve an objective.

Foreign direct investment (FDI) is one of the main generators of economic development. Its inflow has a strong influence on a country's economy. In other words, terrorist activities reduce security and investors' confidence in countries exposed to terrorist activities, reducing the inflow of foreign direct investment. On the other hand, the costs of anti-terrorist security burden the economy and reduce its economic potential. The economic effects of international terrorism are evident in the short and long run. In the short run, terrorism results in material losses, casualties and creation of a negative investment climate. In the long run, international terrorism affects the price increase due to increased spending on national security and anti-terrorist activities. In this way, security costs are incurred by all users of products in the international market, in addition to the country threatened by terrorism.

The research is based on the hypothesis that terrorism and terrorist activities have a negative impact on the inflow of foreign direct investment in the selected countries of the European Union (EU) and countries of the European Economic Area (EEA). The main objective of the research is to systematically analyse and define institutional, economic, natural and terrorism factors and test their impact on FDI inflow in the selected countries and propose measures to improve security in order to create a safe investment environment.

The research consists of six interrelated parts. After the introduction, the second part of the research presents previous research covering direct foreign investment and terrorist activities. Methodological framework of the research are presented in the third part. The fourth part of the research includes the construction of an econometric model and background documentation. The fifth part shows the results of the conducted empirical research on the example of the EU and EEA countries. The sixth part of the research sets out the proposals and recommendations and concluding observations. 


\section{Literature review}

Terrorism and related implications are covered by a number of research and scientific discussions. The previous research presented below covers the topical issues of tackling the problem of terrorism and its economic repercussions.

Scientific research, mostly by foreign authors is a proof of the growing interest of scientists in the study of the impact of terrorism on security and FDI inflow. The interest is especially encouraged by current acts of terrorism (September 11, Madrid, London, the Middle East, but also events in Ukraine). Economic causes and effects of international terrorism are examined as well as various economic aspects of the lack of a unified security policy. Previous analysis of economic consequences of terrorist activities presented by some authors has not sufficiently contributed to the creation of economic models aimed at measuring the effects of terrorist activities, which should have been the end results of these analyses.

The impact of terrorism on the inflow of FDI is still an insufficiently analysed topic, and this is a theoretical and practical justification of this research. The research conducted by Abadie and Gandeazab (2003) is based on the insight into terrorist activities that have caused increased global insecurity with a negative impact on the distribution and transfer of capital and investment inflow in different countries.

The world financial system, due to globalisation effects and the removal of barriers to the free movement of factors of production, is becoming more open. Alomar and El-Sakka (2011) have, on the basis of research conducted in 136 developing countries, found a negative impact of terrorism on FDI inflow. Tavares (2004) found in his research that increased activities of international terrorism also affect the economic development of the country at risk of terrorism. He measured the damage caused by terrorist activities to the economies of developing countries. Furthermore, he proved that intensified terrorist activities result in a reduction of tax and general total government revenues in some countries, which has a negative impact on their economies.

By using an extended gravity model, Volker and Schumacher (2004) found that an increased terrorist activity reduces economic growth by $4 \%$. The study was conducted on a group of countries in the period between 1960 and 1993. Blomberg et al. (2004) have found that on average, the incidence of terrorism may have an economically significant negative effect on growth, albeit one that is considerably smaller and less persistent than that associated with either external wars or internal conflict. Moreover, Mehmood (2013) has highlighted the economic impact of terrorism on major macroeconomic variables of Pakistan. The finding of terrorism affect on the Pakistani macroeconomy lasting for as long as 2 years is also consistent with Pakistan's sensitivity and vulnerability to shocks hypothesis. The study has estimated the direct cost of post 9/11 terrorism to be around 7 billion in US dollars. Gries et al. 
(2009) analysed the role of economic performance in determining terrorist violence of terrorism. The findings confirmed that economies under attack are successful in adjusting to the threats of terror, soeconomic growth is not impaired.

Furthermore, the results of a study (Pizam and Fleisher, 2001) conducted on the impact of acts of terrorism on tourism demand in Israel during the period of May 1991-May 2001, confirmed that the frequency of acts of terrorism had caused a larger decline in international tourist arrivals than the severity of these acts. The implications of this study are that tourist destinations can recover from even severe acts of terrorism, as long as the terrorist acts are not repeated.

On the other hand, Lutz and Lutz (2014) proved that terrorism did not have the expected effects on international economic activities in sub-Saharan Africa. For the region as a whole, there was very little indication that terrorism, either in terms of incidents or fatalities had the anticipated negative effects on foreign investment and foreign visits.

The negative impact of terrorism on economic growth was covered by James et al. (2006) and concluded that the private sector and foreign investment are more severely affected by the uncertainty and dangers of terrorism. This study shows a positive correlaton between the new inflow of foreign investment and economic growth in each country.

The cost effects of terrorism on individual countries can be viewed from several aspects. The most important ones relate to the lack of FDI and their redirection to other countries, devastation of infrastructure, investment of public funds into increasing security rather than investing in development, and trade restrictions. Developing countries that are more dependent on foreign capital are facing reduced economic growth caused by the reduced inflow of FDI. As civil war may affect the outflow of capital from a country (Collier and Sambanis, 2002), sufficiently strong terrorist activity can reduce the inflow of capital (Enders; Sandler, 1996).

Terrorism (and civil wars) may cause overflow of costs among neighbouring countries and divert capital inflows in the event of security risks in the neighbouring country. Also, increased danger of terrorism may affect the reduction of economic activity across the region. The example of terrorist attacks in the USA in 2001 shows that terrorism can have negative effects on particular sectors or branches of industry (air transport and tourism) (Drakos, 2004, Ito and Lee, 2004) or result in a drastic increase in spending on necessities for the establishment of national security (Enders; Sandler, 2006). Terrorism also affects the increase in operating costs, which is reflected through high insurance premiums, higher spending on security and higher wages for employees at risk. In 2005, Blomberg and Mody analysed quantitative impacts of terrorism using a gravity model of bilateral FDI flows that included 12 countries of origin and 43 host countries in the period between 1981 and 1988. This model separates the effects of terrorism on FDI from the effects 
of other forms of insecurity/violence on FDI. The research results, for the most part applicable to developing countries, show how insecurity/violence in the host countries has a negative and significant impact on FDI while on the other hand, insecurity/violence in the country of origin results in an outflow of FDI.

Taking into account investment determinants, Tarzi in 2005 tried to identify the key factors of investment inflow in a particular country, i.e. to determine why certain developing countries have high FDI inflows, while inflows in other countries are minimal. The most important identified factors are market size, market growth rate, competitiveness of the economy, infrastructure, and productivity of the employees. Also, the author points out the importance of legislation in the host country with a particular focus on the policies that encourage investment, taxation, repatriation, rules for property acquisition for foreign citizens, FDI regulations, labour policy, etc. He also took into account company characteristics, such as company size, business sector, types of industry, and strong and sustainable strategies. Emphasis was also placed on product differentiation factors, among which the most important are technology, brand, marketing activities, skills, logistics, and organisation, that can be the foundations of international competitiveness of a particular company. Finally, the research indicate far-reaching consequences of terrorist activities, not only on FDI, but also on other economic parametres such as the gross domestic product of other countries.

\section{Methodology}

The impact of terrorism on FDI is the basis for testing the impact of the factors by applying the system GMM two-step estimation of the dynamic panel model.

Two forms of dynamic estimators were developed on the basis of the GMM method: differentiated GMM estimator (Arellano and Bond, 1991) and system GMM estimator (Arellano and Bover, 1995; Blundell and Bond, 1998). Differentiated and system GMM estimators have been created for the purpose of dynamic panel analysis and have certain assumptions of data generating process (Roodman, 2009), which should be considered, i.e. that:

- There is a possibility of autonomously distributed individual time-invariant effects. Such a situation is contrary to the temporal regression model;

- Some of the regressors can be endogenous,

- The occurrence must be dynamic in nature, with the realisation of the current dependent variable that is influenced by the variable from former periods,

- Idiosyncratic disorders (except for time-invariant effects) have specific forms of heteroscedasticity, autocorrelation, and 
- Idiosyncratic disorders are uncorrelated between individual variables.

The dynamic model with a single time-shifted (lagged) variable can be shown by the following equation (1):

$$
y_{i t}=\beta y_{t-1}+u_{i}+v_{i t},|\beta|<1
$$

wherein $y_{i t}$ is the value of the dependent variable also in the period $t ; y_{t-1}$ is the dependent variable with a shift (lag) for one period; $u_{i}$ are individual time-invariant effects, and $v_{i t}$ is a random error. Individual impacts are treated as stochastic, and further assumption that is crucial for the consistency of the model is that errors $v_{i t}$ are serially uncorrelated. Individual time-invariant effects are initially associated with the former influence of the dependent variable of the model, which points to the above-mentioned problem of endogeneity.

In exceptional cases, when there is no serial correlation (autocorrelation) in the random error, lagged differences i.e. shifts of endogenous variables can be included as instruments of the model (Arellano and Bond, 1991; Greene, 2005; Stojčić et al., 2011; Stojčić and Hashi, 2011; Stojčić et al., 2012).

It is expected that the research will show significant impact of terrorism on incoming FDI per capita in the observed group of EU countries and EEA countries. It is not expected that the role of natural disasters on incoming FDI per capita will be significant. Furthermore, it is assumed that the economic variable GDP per capita has a certain effect in the context of an increase in the incoming FDI per capita. The variable of capital openness and financial climate should have a positive sign, but also a great impact on incoming FDI per capita. FDI is a process that develops over time. Proving the above predictions may provide an answer to the question of significance of the impact of terrorism on the FDI of the selected EU and EEA countries. These assumptions of the empirical part will be subjected to econometric testing in order to confirm the main hypotesis of the research. Based on the given model, relevant variables are selected and tested. The econometric model is as follows:

$$
\begin{aligned}
& \text { FDIpc }_{i t}=\beta_{0}+\beta_{1} \operatorname{FDIpc}(-1)_{i(t-1)}-\beta_{1} \operatorname{INCIDENTS}_{i t}-\beta_{2} \text { DISASTERS }_{i t}+ \\
& +\beta_{4} \text { GDPpc }_{i t}+\beta_{5} k_{\text {a_open }}+\sum_{t=2002}^{2013} \text { godina }_{t}+u_{i t}+v_{i t}
\end{aligned}
$$

The state of incoming foreign direct investment per capita (FDIpc) is selected to be a dependent variable in the econometric model (2). As a dependent variable, FDI includes equity capital, reinvested earnings and intra-company loans. The FDI inflow represents a direct or indirect investment of a foreign investor. The data are taken from the reference database UNCTAD (2015). Arguments that support the selection of the dependent variable of foreign direct investment can be found in empirical studies that confirm the negative impact of terrorist attacks on foreign 
direct investment. For example, Enders and Sandler (1996) observed countries such as Greece and Spain. Their results showed the decline in net FDI inflow by $13.5 \%$ and $11.9 \%$, which was caused by the terrorist attacks in the period between 1975 and 1995. Enders, Sachsida and Sandler (2006) used time series analysis and panel analysis by which they proved the negative impact of international terrorism on American direct investment outflows. Filer and Stanišić (2012) analysed the impact of terrorism on capital inflows of 160 countries over a period of 25 years. The authors conclude that terrorist attacks can significantly reduce the foreign direct investment flow with no effect on foreign debt and investment portfolio.

The following variables were selected as independent variables of the model, including the natural logarithm of the state of incoming foreign direct investment from the previous year $(F D I p c(-1))$, the number of incidents (INCIDENTS), GDP per capita $(G D P p c)$, the KAOPEN Index ( $\left.k a \_o p e n\right)$, and natural disasters (DISASTERS). FDIpc(-1) represents the state of incoming foreign direct investment per capita in the previous year and, simultaneously, the time-shifted variable.

Another independent variable is the INCIDENTS variable that represents the total number of terrorist attacks, i.e. incidents. The data were collected from the reference database Global Terrorism Database (2015). A number of empirical studies (Kang and Lee, 2007; Agrawal, 2011; Bandyopadhyay et al. 2011; Filler and Stanišić, 2012; Shahbaz et al., 2013) include the number of terrorist incidents and/or casualties of terrorism as independent variables of the model. The conducted studies generally confirm the negative impact of terrorism on foreign direct investment. Therefore, in this study, the variable INCIDENTS is selected, that measures the impact of terrorism on foreign direct investment. The model includes the economic variable GDP per capita $(G D P p c)$ in the selected EU and EEA countries. The values of GDP per capita of the observed countries were collected from the reference database UNCTAD (2015). They are denominated in US dollars and shown through constant prices and constant exchange rates from 2005. The equation of the model involves the so-called Chinn-Ito (KAOPEN) Index measuring observed countries' degree of capital account openness. The variable $k a_{-}$ open represents the institutional variable of the model and at the same time shows the characteristics of the financial climate in a particular country. The KAOPEN Index is based on binary "dummy" variables that show the limitations of crossborder financial transactions of the Annual Report on Exchange Arrangements and Exchange Restrictions (AREAER) by the IMF. The Index was originally developed by Chinn and Ito (2006) and is applicable to the studies of the impact of terrorism on foreign direct investment by Filler and Stanišić (2012). The econometric analysis includes the variable of natural disasters (DISASTERS), whose data were downloaded from the International Disasters Database (2016). The natural disasters variable is treated as an independent variable in studies by authors such as Stanišić (2012), Sanjo (2011) who confirm the negative impact of natural disasters on the 
inflow of FDI. The variable $\mathrm{u}$ indicates individual time-fixed effects, while $\mathrm{v}$ is the random error of the model. The impact of omitted variables is measured by the effects of the constant.

\section{Empirical data and analysis}

Empirical part of the research is based on secondary research by the authors. The research results relate to the period from 2000 to 2013. The econometric model consists of a total of 29 European economies at very high risk, high risk, medium risk, low risk, insignificant risk, or no risk of terrorist attacks. The group of selected countries includes the EU and EEA Member States, i.e. Austria, Bulgaria, Cyprus, Croatia, the Czech Republic, Denmark, Estonia, Finland, France, Germany, Greece, Hungary, Ireland, Italy, Latvia, Lithuania, Malta, the Netherlands, Poland, Portugal, Romania, Slovakia, Slovenia, Spain, Sweden, the United Kingdom, Switzerland, Norway, and Iceland. The countries' values are listed in Table A2 in Appendix. The classification of the analysed countries is downloaded from the website of Crisis Management Web Analytics from 2015.

By using a dynamic model, the potential problems of endogeneity and measured errors can be eliminated by using instruments i.e. temporal shifts (lags) of the dependent variable. Implementation of the dynamic panel eliminates the problems that can affect reliability and assessment of the results of the empirical analysis. Diagnostics of the model is conducted first, and the impact will be tested by the selection of the dynamic panel. The significance of the impact of terrorist incidents and other independent variables on FDI inflow is tested by using the system twostep GMM estimator. The dynamic panel analysis is based on the implementation of the econometric tool GRETL. The results monitor the impact of the selected independent variables of foreign direct investment from the previous year $(F D I p c(-1))$, the number of incidents (INCIDENTS), GDP per capita (GDPpc), the values of KAOPEN Index (ka_open), and natural disasters (DISASTERS) on the dependent variable FDIpc. The results of the assessment and diagnosis of the dynamic panel model are presented on the example of the dependent variable FDIpc. Detailed printout of the results of the system two-step GMM estimator can be found in Table A1 in Appendix. 
Table 1: Results of the Dynamic Panel of System GMM Estimator from 2000 to $2013^{*}$

\begin{tabular}{|l|c|}
\hline \multicolumn{1}{|c|}{ INDEPENDENT VARIABLES } & VALUE \\
\hline Lagged dependent variable FDIpc(-1) & $0.504353^{* * *}$ \\
\hline INCIDENTS & $-5.76717^{* * *}$ \\
\hline DISASTERS & -7.68247 \\
\hline GDPpc & $0.0161146^{* * *}$ \\
\hline ka_open & $576.131^{* * *}$ \\
\hline Constant $\quad$ MODEL DIAGNOSTICS & $-384.246^{* * *}$ \\
\hline & VALUE \\
\hline Number of observations & 377 \\
\hline Number of instruments & 95 \\
\hline Wald test & $1.63313 \mathrm{e}+006$ \\
\hline Prob $>$ chi2 & 0.000 \\
\hline Sargantest & 25.2068 \\
\hline Prob $>$ chi2 & 1.0000 \\
\hline Arellano-Bond test for AR(1) in the first differenced errors & -2.16719 \\
\hline Prob $>$ chi2 & 0.0302 \\
\hline Arellano-Bond test for AR(2) in the first differenced errors & -0.9103 \\
\hline Prob $>$ chi2 & 0.3627 \\
\hline
\end{tabular}

Note: ${ }^{*}$ dependent variable FDIpc. P-values in parentheses and labels ${ }^{* * *}$ indicate the level up to $1 \%$ significance. P-values were obtained by calculating the two-step dynamic procedure.

Source: Authors' calculations

Table 1 indicates following results. The results of the Wald test indicate a sufficient explanatory power of the variables of the model, which is confirmed by the respective significance of the test. The synthesis of the diagnostics results leads to the conclusion that the model is specified in the appropriate manner. It can be concluded that the model can be subjected to econometric testing of the impact of independent variables on the dependent variable.

The resulting value (Prob $>$ chi2) of the Sargan test amounts to 1.0000 and is higher than 0.05 , which means that the model is acceptable and correct. Arellano-Bond test is used to examine the existence of autocorrelation of the first (AR1) and the second order of errors (AR2) in the first differences of the equation. The results of Arellano-Bond (2) tests do not indicate the presence of the second-order autocorrelation due to 0.36 coefficient, which is higher than the allowable limit of 0.05 . Therefore, the null hypotheses of no second-order autocorrelation are fully accepted. The coefficients have the expected signs and satisfactory statistical significance. 


\section{Results and discussion}

After reviewing the results of model diagnostics, the results are interpreted through GMM estimation. There is an evident positive and highly significant coefficient of temporally shifted (lagged) dependent variable $F D I p c(-1)$, which supports the thesis that the current values are positively related to the previous realisations. In other words, the magnitude of the coefficient shows that a $1 \%$ increase in the value of incoming foreign direct investment per capita from the previous period results in an increase of $0.50 \%$ in the current period with provided constancy of other variables of the model. Incoming foreign direct investment per capita will be reduced by $5.76 \%$ if the variable number of incidents is increased by $1 \%$, provided ceteris paribus. The value of incoming foreign investments per capita results in an increase of $0.01 \%$ if GDP per capita is increased by $1 \%$ provided the constancy of other variables of the model. Incoming foreign direct investment per capita increases by $576.1 \%$ if the variable $k a \_o p e n$ increases by $1 \%$, provided the constancy of other variables of the model. The DISASTERS variable has the expected sign, but its significance is unsatisfactory.

The results indicate a positive and statistically significant impact of terrorism on incoming FDI per capita. The impact of natural disasters on incoming FDI per capita is relatively weak and insignificant. There is a recorded statistically significant impact of GDP per capita on the incoming FDI per capita. The highly significant impact of the KAOPEN Index on the incoming FDI per capita has been confirmed as well. According to which incoming FDI is a process that develops over a period of time. One should not ingore the fact that FDI may be the result of FDIs from previous periods. It is evident that direct foreign investment do not provide short-term tangible results. The significance of the lagged variable may indicate that previous FDI of a company provides a clear picture of a favourable investment climate in a country and further attracts other companies and their FDI. Since on the basis of the conducted research, by using the appropriate scientifically based methodology, the negative impact of terrorist activities on the inflow of foreign direct investment has been confirmed, confirmation of the basic hypothesis of the research also results from the conclusions listed below.

\section{Conclusion}

The basis hypothesis of the research is confirmed, pointing out that terrorism and terrorist activities have a negative impact on the inflow of foreign direct investment in the selected countries of the European Union (EU) and countries of the European Economic Area (EEA). The research results confirm that terrorism has a negative impact on the security of the inflow of foreign direct investment in the selected countries. The consequence are anti-terrorist security costs that burden the economy 
and reduce its competitive potential, and at the same time have an impact on an increase in fprices of products in the affected countries. The results derived from this research have contributed to the scientific approach in the research of the impact of terrorism on the inflow of FDI in the EU and EEA countries through the presentation of new facts and their interpretation. The methodological approach was used (the use of GMM estimators in the two-step dynamic panel analysis). The limitation of this scientific research is reflected in the selection of a limited number of the observed countries. The presented models can be methodologically complemented and developed and, depending on the objectives and interests of interested professionals, it is possible to add new variables to the models. In accordance with the conclusions of the conducted research, the following guidelines for increasing security resulting from anti-terrorist activities and increasing the FDI are adopted. Recipient countries should increase awareness of the circumstances and trends of FDI inflows in the world. World FDI flows are significantly reduced due to the consequences of the global financial crisis, especially in the EU and the USA, but also in BRICS countries. The competition for their attraction has intensified, especially among developed countries. In order to attract FDI, countries should revise their foreign trade policy (tariff and non-tariff barriers) and strengthen their regulatory environment. Pre-designed security policy can be used to alleviate the negative consequences of the impact of terrorism on FDI. The recommendation especially refers to the effects of foreign direct investment on economies of countries in which foreign investors invest their capital, the effects of terrorism on the economies of countries exposed to terrorist activities, as well as the prevention of terrorist attacks and avoiding the negative effects on the inflow of foreign direct investment and economic growth. The countries receiving FDI must be clear about the negative impact of terrorism on international exchange. Terrorism results in enhancement of security measures and control. In addition to the fact that such instruments are economically unproductive, they aggravate foreign trade activities and in turn influence the decline of the trade volume. This is supported by enhanced security measures after the terrorist attacks in the USA (September 11) that reflected negatively on the flow of the world trade. If funds were (partly) allocated for education, science or infrastructure, productivity of these countries would be higher, and the countries would achieve a higher level of international competitiveness. The countries receiving FDI should anticipate changes brought about by the increase in their political risk. The growth of political risk as a result of the geopolitical crisis in these countries adversely affects investment plans of FDI holders and causes a slowdown in the growth of global economy. Moreover, the negative implications of terrorist incidents weaken investors' confidence, and this is the key element in encouraging FDI inflows. The countries in the region should develop awareness of the negative implications of terrorist activities on their economic growth. Terrorism slows down/eliminates the inflow of FDI in these countries. Terrorism can result in property damage, casualties, costs of medical treatment, damage to the infrastructure and trade restrictions. In case of a larger terrorist act, the production capacity of these coutries 
is threatened. However, it has to be stressed out that, in some cases, terrorism could affect positively on FDI, performance of some industrial sectors (maufacture of gun and armory) The application of the results of this research may contribute to a clearer perception of the impacts of terrorism on FDI. Ignoring the possibilities of occurrence of terrorist activities may have a long-term negative impact on the economic situation in a country. Terrorism has negative effects on the economic growth but this effect is depending about the social, political structure of observed country. In some cases of countries which unsucessfully confront to the effects of terrorism for periods of time, there is no relationship between terrorism and investments. Anyways, it cannot be applied on the EU case. Interruption of FDI inflow as one of the most important factors of savings affects slowdown of economic growth. Moreover, terrorism can be manifested through negative overflow effects on neighbouring countries by substantial withdrawal of capital. Ultimately, economic growth slows down, not only in one country, but also throughout the region.

\section{References}

Abadie, G. Gardeazabal, J. (2003) "The economic costs of conflicts: A case study of the basque country", The American Economic Review, Vol. 93, No. 1, pp. 113-132, doi: 10.3386/w8478.

Agrawal, S. (2011) "The Impact of Terrorism on Foreign Direct Investment: Which Sectors are More Vulnerable?", CMC Senior Theses, Paper 124, available at: http:// scholarship.claremont.edu/cgi/viewcontent.cgi? article $=1184 \&$ context $=\mathrm{cmc}$ theses.

Alomar, M., El-Sakka, T. (2011) "The Impact of Terrorism on the FDI Inflows to Less Developed Countries: A Panel Study", European Journal of Economics, Finance and Administrative Sciences, Vol. 28., pp.116-125, available at: https:// www.researchgate.net/publication/287627707_The_impact_of_terrorism_on_ the_FDI_inflows_to_less_developed_countries_A_panel_study.

Arellano, M., Bond, S. (1991) "Some tests of specification for panel data: Monte Carlo evidence and an application to employment equations", The Review of Economic Studies, Vol. 58, No. 2. pp. 277-297, doi: 10.2307/2297968.

Arellano, M., Bover, O. (1995) "Another Look at the Instrumental Variable Estimation of Error-Components Model", Journal of Econometrics, Vol. 68, No.1, pp. 29-51, doi: 10.1016/0304-4076(94)01642-d.

Bandyopadhyay, S., Sandler, T., Younas, J. (2011) "Foreign direct investment, aid, and terrorism: an analysis of developing countries", Federal Reserve Bank of St. Louis, Working Paper 2011-004A, doi: 10.2139/ssrn.1745142.

Blomberg, B., Moby, A. (2005) "How Severly Does Violence Deter International Investment?", Claremont Colleges Economics Departments, Working Paper 2005-01, doi: 10.2139/ssrn.722812. 
Blomberg, S. B., Hess, G. D., Orphanides, A. (2003) "The macroeconomic consequences of terrorism", Journal of Monetary Economics, Vol. 51, No. 5, pp. 1007-1032, doi: 10.1016/j.jmoneco.2004.04.001.

Blundell, R., Bond, S. (1998) "Initial Conditions and Moment Restrictions in Dynamic Panel Data Models", Journal of Econometrics, Vol. 87, No.1, pp. 115-143, doi: 10.1016/s0304-4076(98)00009-8.

Collier, P., Sambanis, N. (2002) "Understanding Civil Wars: A New Agenda”, Journal of Conflict Resolution, Vol. 46, No. 1, pp. 3-12, doi: 10.1177/0022002702046001001.

Crisis Management Web Analytics (2016), http://www.riskmap.aon.co.uk/ Terrorism_Risk_Map.aspx.

Drakos, K. (2004) "Terrorism-Induced Structural Shifts in Financial Risk: Airline Stocks in the Aftermath of the September $11^{\text {th }}$ Terror Attacks", European Journal of Political Economy, Vol. 20, No. 2, pp. 435-446, doi: 10.1016/j. ejpoleco.2003.12.010.

Enders, W., Sandler, T. (1996) "Terrorism and Foreign Direct Investment in Spain and Greece", Kyklos, Vol. 49, No. 3, pp. 331-352, doi: 10.1111/j.14676435.1996.tb01400.x.

Enders, W., Sandler, T. (2006) The Political Economy of Terrorism, Cambridge University Press, $3^{\text {rd }}$ Edition, doi: 10.1017/cbo9780511791451.011.

Filer, R., Stanišić, D. (2012) "The effect of terrorist incidents on capital flows", CERGE-EI Working Paper Series, 480, doi: 10.2139/ssrn.2257389.

Greene, W. H. (2005) Econometric Analysis ( $5^{\text {th }}$ International Edition), Prentice Hall.

Gries, T., Krieger, T., Meierrieks, D. (2011) "Causal Linkages Between Domestic Terrorism and Economic Growth", Defence and Peace Economics, Vol. 22, No. 5, pp. 493-508, doi: 10.1080/10242694.2010.532943.

Ito, H., Lee, D. (2004) "Assessing the Impact of the September 11 Terrorist Attacks on US Airline Demand", Journal of Economics and Business, Vol. 57, No. 1, pp. 75-95, doi: 10.2139/ssrn.722491.

International Disasters Database (2016) Available at: http://www.emdat.be.

James, B. R. et al. (2006) "Economic Impacts of Global Terrorism: From Munich to Bali", available at: http://ssrn.com/abstract=892033 or doi: 10.2139 / ssrn.892033.

Kang, S. J., Lee, H. S. (2007) “Terrorism and FDI Flows: Cross-Country Dynamic Panel Estimation", Journal of Economic Theory and Econometrics, Vol. 18, No. 1, pp. 57-77, available at: http://www.apeaweb.org/confer/hito05/papers/ kang_s.pdf.

Lutz, J. B., Lutz, M. J. (2014) "Terrorism and Its Impact on Foreign Economic Activity in Sub-Saharan Africa", Journal of Business and Economics, Vol. 5, No. 4, pp. 525-534, available at: http://www.academicstar.us/UploadFile/ Picture/2014-6/201461445249331.pdf. 
Mehmood, S. (2013) "Terrorism and the macroeconomy: Evidence from Pakistan", Defence and Peace Economics, Vol. 25, No. 5, pp. 509-534, doi: 10.1080/10242694.2013.793529.

Pizam, A., Fleischer, A. (2002) "Severity versus Frequency of Acts of Terrorism: Which Has a Larger Impact on Tourism Demand?", Journal of Travel Research, Vol. 40, No. 3, pp. 337-339, doi: 10.1177/0047287502040003011.

Roodman, D. (2009) "A Note on the Theme of Too Many Instruments", Oxford Bulletin of Economics and Statistics, Vol. 71, No. 1, pp. 135-158, doi: 10.1111/j.1468-0084.2008.00542.x.

Shahbaz, M. A., Javed, A., Amina, D., Sattar, T. (2013) "Performance Measurement of Small and Medium Enterprises (SMEs) in Pakistan", Archives of Business Research, Vol. 2, No. 3, doi: 10.14738/abr.23.320.

Statistical Database UNCTAD (2016) available at: http://www.unctad.org.

Stojčić, N., Hashi, I., Shqiponja, T. (2011) "Innovation Activities and Competitiveness: Empirical Evidence on the Behaviour of Firms in the New EU Member States and Candidate Countries", CASE Network Studies and Analyses, No. 424, Warsaw: CASE - Center for Social and Economic Research, doi: $10.2753 /$ eee0012-8775510404.

Stojčić, N., Hashi I. (2011) "The Structure and Quality Upgrading of Croatian Exports to EU15 Market, paper presented at the 9th International Conference, Challenges of Europe: Growth and Competitiveness - Reversing the Trends", organized by the University of Split, Faculty of Economics, Bol, Croatia, May 26-28, available at: http://search.proquest.com/openview/30a746e4f0dd861 ee1 79eff2eb3ae88b/1?pq origsite $=$ gscholar.

Stojčić, N., Bečić, M., Vojinić, P. (2012) "The Competitiveness of Exports from Manufacturing Industries in Croatia and Slovenia to the EU-15 Market: A Dynamic Panel Analysis", Croatian Economic Survey: Vol. 14, No. 1, pp. 69-105, available at: http://hrcak.srce.hr/80034.

Tarzi, S. (2005) "Foreign Direct Investment flows into Developing Countries: Impact Location and Government Policy", Journal of Social, Political and Economic Studies, Vol. 30, No. 4, pp. 497-515, available at: https://www. questia.com/library/journal/1P3-948618511/foreign-direct-investment-flowsinto-developing-countries.

Tavares, J. (2004) "The Open Society Assesses Its Enemies: Shocks, Disasters and Terrorist Attacks", Journal of Monetary Economics, Vol. 51, No. 5, pp. 10391070, doi: 10.1016/j.jmoneco.2004.04.009.

Volker, N., Schumacher D. (2004) "Terrorism and international trade: an empirical investigation", European Journal of Political Economy, Vol. 20, No. 2, pp. 423-433, doi: 10.1016/j.ejpoleco.2003.12.009. 


\title{
Utjecaj terorizma na izravna strana ulaganja (FDI) zemalja EU i EEA ${ }^{1}$
}

\author{
Heri Bezić ${ }^{2}$,Tomislav Galović ${ }^{3}$, Petar Mišević ${ }^{4}$
}

\begin{abstract}
Sažetak
Glavni cilj istraživanja je empirijski odrediti učinke terorizma na izravna strana ulaganja (FDI) odabranih EU i EEA zemalja. Metodologija se temelji na primjeni sistemskog GMM procjenitelja dinamičke panel analize, obuhvaća grupu od 29 zemalja, razdoblje od 13 godina i to u periodu od 2000. do 2013. godine. Glavni rezultati potvrđuju kako teroristički incidenti, ekonomske i institucionalne varijable utječu na izravna strana ulaganja promatranih EU i EEA zemalja. Može se zaključiti kako su terorizam i institucionalna stabilnost zabilježile najznačajniji utjecaj na priljev FDI promatranih EU i EEA zemalja. Rezultati ukazuju kako terorističke aktivnosti smanjuju sigurnost $i$ povjerenje ulagača u zemlje koje mogu biti pod utjecajem terorističkih aktivnosti, smanjujući im priljev inozemnih direktnih ulaganja. Preporuke i prijedlozi su dane temeljem rezultata empirijske analize.
\end{abstract}

Ključne riječi: terorizam, GMM procjenitelj, FDI (izravna strana ulaganja), EU, EEA

JEL klasifikacija: F52, F59, F21, F62

1 Ovaj rad je financiralo Sveučilište u Rijeci projektom pod brojem 13.02.1.3.13.

${ }^{2}$ Redoviti profesor u trajnom zvanju, Sveučilište u Rijeci, Ekonomski fakultet, Ivana Filipovića 4, 51000 Rijeka, Republika Hrvatska. Znanstveni interes: tehnološka politika i konkurentnost, međunarodno poslovanje.Tel.: + 38551355 148.E-mail: bezic@efri.hr.

${ }^{3}$ Docent, Sveučilište u Rijeci, Ekonomski fakultet, Ivana Filipovića 4, 51000 Rijeka, Republika Hrvatska. Znanstveni interes: tehnološka politika i konkurentnost, međunarodno poslovanje. Tel.: +38551355155.E-mail:tgalovic@efri.hr.

4 Dr.sc., zaposlen u Hrvatskoj gospodarskoj komori, Roosveltov Trg 2, 10000 Zagreb, Republika Hrvatska.E-mail:pmisevic@hgk.hr. 

Heri Bezić, Tomislav Galović, Petar Mišević • The impact of terrorism on the FDI...

Zb. rad. Ekon. fak. Rij. • $2016 \cdot$ vol. $34 \cdot$ no. $2 \cdot 333-362$

\section{Appendices}



Heri Bezić, Tomislav Galović, Petar Mišević • The impact of terrorism on the FDI...

Table A1: Results of the System Two-Step GMM Estimator

Model 4: 2-step dynamic panel, using 377 observations

Included 29 cross-sectional units

Including equations in levels

H-matrix as per Ox/DPD

Dependent variable: FDIpc

Asymptotic standard errors

\begin{tabular}{|l|r|r|r|r|l|}
\hline & \multicolumn{1}{|c|}{ Coefficient } & \multicolumn{1}{c|}{ Std. Error } & \multicolumn{1}{c|}{ Z } & \multicolumn{1}{c|}{-value } & \\
\hline FDIpc(-1) & 0.504353 & 0.000406775 & 1239.8818 & $<0.0001$ & $* * *$ \\
\hline const & -384.246 & 102.908 & -3.7339 & 0.0002 & $* * *$ \\
\hline GDPpc & 0.0161146 & 0.000932268 & 17.2853 & $<0.0001$ & $* * *$ \\
\hline DISASTERS & -7.68247 & 15.5508 & -0.4940 & 0.6213 & \\
\hline INCIDENTS & -5.76717 & 1.63973 & -3.5171 & 0.0004 & $* * *$ \\
\hline ka_open & 576.131 & 145.379 & 3.9630 & $<0.0001$ & $* * *$ \\
\hline
\end{tabular}

Sum squared resid

Number of instruments $=95$

Test for AR(1) errors: $\mathrm{z}=-2.16719[0.0302]$

Test for AR(2) errors: $\mathrm{z}=-0.9103$ [0.3627]

Sargan over-identification test: Chi-square(89) $=25.2068$ [1.0000]

Wald (joint) test: Chi-square(5) $=1.63313 \mathrm{e}+006[0.0000]$

Source: Authors' calculations

Table A2: Values of Variables of the Model

\begin{tabular}{|l|c|r|r|c|c|c|}
\hline \multicolumn{1}{|c|}{ Country } & Year & \multicolumn{1}{c|}{ FDIpc } & \multicolumn{1}{c|}{ FDIgdp } & ka_open & INCIDENTS & DISASTERS \\
\hline Austria & 2000 & 1059,94211 & 4,32794366 & 1 & 0 & 1 \\
\hline Austria & 2001 & 706,811225 & 2,8887434 & 1 & 0 & 0 \\
\hline Austria & 2002 & 17,097106 & 0,06495735 & 1 & 0 & 1 \\
\hline Austria & 2003 & 760,84216 & 2,37619915 & 1 & 0 & 1 \\
\hline Austria & 2004 & 388,574227 & 1,06167574 & 1 & 0 & 0 \\
\hline Austria & 2005 & 1309,01546 & 3,42754199 & 1 & 0 & 1 \\
\hline Austria & 2006 & 574,426914 & 1,42233551 & 1 & 1 & 0 \\
\hline Austria & 2007 & 3066,15901 & 6,59463988 & 1 & 1 & 1 \\
\hline Austria & 2008 & 866,217405 & 1,68981165 & 1 & 6 & 1 \\
\hline Austria & 2009 & 1107,09748 & 2,33123507 & 1 & 3 & 0 \\
\hline Austria & 2010 & 306,532613 & 0,66095808 & 1 & 0 & 0 \\
\hline Austria & 2011 & 1258,83892 & 2,47393657 & 1 & 1 & 0 \\
\hline
\end{tabular}


Heri Bezić, Tomislav Galović, Petar Mišević • The impact of terrorism on the FDI... Zb. rad. Ekon. fak. Rij. • $2016 \cdot$ vol. $34 \cdot$ no. $2 \cdot 333-362$

\begin{tabular}{|c|c|c|c|c|c|c|}
\hline Country & Year & FDIpc & FDIgdp & ka_open & INCIDENTS & DISASTERS \\
\hline Austria & 2012 & 471,27868 & 0,97868544 & 1 & 0 & 1 \\
\hline Austria & 2013 & 1221,35807 & 2,42238676 & 1 & 1 & 1 \\
\hline Bulgaria & 2000 & 127,052661 & 7,61186994 & 0,224489 & 2 & 2 \\
\hline Bulgaria & 2001 & 101,881364 & 5,65180477 & 0,163896 & 1 & 0 \\
\hline Bulgaria & 2002 & 117,183183 & 5,64315075 & 0,163896 & 1 & 0 \\
\hline Bulgaria & 2003 & 267,52026 & 9,89761282 & 0,224489 & 0 & 0 \\
\hline Bulgaria & 2004 & 438,644868 & 13,1063635 & 0,285083 & 0 & 0 \\
\hline Bulgaria & 2005 & 510,195397 & 13,3787383 & 0,345677 & 0 & 3 \\
\hline Bulgaria & 2006 & 1023,88109 & 23,1940897 & 0,939406 & 0 & 1 \\
\hline Bulgaria & 2007 & 1638,05736 & 28,3912574 & 1 & 0 & 1 \\
\hline Bulgaria & 2008 & 1313,27775 & 18,4844231 & 1 & 2 & 1 \\
\hline Bulgaria & 2009 & 454,641943 & 6,74888091 & 1 & 0 & 0 \\
\hline Bulgaria & 2010 & 209,648419 & 3,18296697 & 1 & 0 & 0 \\
\hline Bulgaria & 2011 & 401,619833 & 5,28115657 & 1 & 2 & 0 \\
\hline Bulgaria & 2012 & 233,200187 & 3,22722314 & 1 & 2 & 1 \\
\hline Bulgaria & 2013 & 254,360802 & 3,37223989 & 1 & 3 & 0 \\
\hline Croatia & 2000 & 221,905213 & 4,56073258 & 0,411093 & 2 & 2 \\
\hline Croatia & 2001 & 227,262313 & 4,33923053 & 0,411093 & 3 & 0 \\
\hline Croatia & 2002 & 216,375133 & 3,5630539 & 0,411093 & 0 & 0 \\
\hline Croatia & 2003 & 406,177418 & 5,16990213 & 0,69703 & 0 & 1 \\
\hline Croatia & 2004 & 288,604858 & 3,05423791 & 0,69703 & 0 & 0 \\
\hline Croatia & 2005 & 406,937874 & 3,93250873 & 0,69703 & 1 & 2 \\
\hline Croatia & 2006 & 750,500891 & 6,51542763 & 0,69703 & 0 & 0 \\
\hline Croatia & 2007 & 1050,4065 & 7,63891688 & 0,69703 & 0 & 1 \\
\hline Croatia & 2008 & 1214,96371 & 7,51912049 & 0,69703 & 2 & 0 \\
\hline Croatia & 2009 & 707,370005 & 4,91251919 & 0,69703 & 1 & 0 \\
\hline Croatia & 2010 & 261,113239 & 1,89845025 & 0,69703 & 0 & 0 \\
\hline Croatia & 2011 & 388,995979 & 2,70248656 & 0,69703 & 0 & 0 \\
\hline Croatia & 2012 & 336,847311 & 2,56870627 & 0,69703 & 0 & 2 \\
\hline Croatia & 2013 & 222,660256 & 1,65053746 & 0,69703 & 2 & 0 \\
\hline Cyprus & 2000 & 1207,59248 & 8,45472119 & 0,163896 & 2 & 1 \\
\hline Cyprus & 2001 & 1324,17469 & 8,99734008 & 0,163896 & 1 & 0 \\
\hline Cyprus & 2002 & 1464,66681 & 9,18373355 & 0,163896 & 0 & 0 \\
\hline Cyprus & 2003 & 1241,90845 & 6,1789214 & 0,411093 & 0 & 0 \\
\hline Cyprus & 2004 & 1490,05771 & 6,3205569 & 0,757624 & 1 & 0 \\
\hline Cyprus & 2005 & 1584,53525 & 6,31221264 & 0,818218 & 0 & 0 \\
\hline Cyprus & 2006 & 2444,23239 & 9,08001717 & 0,878812 & 0 & 0 \\
\hline Cyprus & 2007 & 2904,56541 & 9,35343244 & 0,939406 & 1 & 1 \\
\hline
\end{tabular}


Heri Bezić, Tomislav Galović, Petar Mišević • The impact of terrorism on the FDI...

Zb. rad. Ekon. fak. Rij. • 2016 • vol. $34 \cdot$ no. $2 \cdot 333-362$

\begin{tabular}{|c|c|c|c|c|c|c|}
\hline Country & Year & FDIpc & FDIgdp & ka_open & INCIDENTS & DISASTERS \\
\hline Cyprus & 2008 & 1799,66079 & 5,14309701 & 1 & 0 & 0 \\
\hline Cyprus & 2009 & 4301,97987 & 13,5665998 & 1 & 0 & 0 \\
\hline Cyprus & 2010 & 924,909043 & 3,03218587 & 1 & 0 & 0 \\
\hline Cyprus & 2011 & 2808,14104 & 8,80099406 & 1 & 0 & 0 \\
\hline Cyprus & 2012 & 1455,41863 & 5,04132524 & 0,692209 & 1 & 0 \\
\hline Cyprus & 2013 & 4032,08109 & 14,5379651 & 0,631615 & 9 & 0 \\
\hline $\begin{array}{l}\text { Czech } \\
\text { Republic }\end{array}$ & 2000 & 486,342992 & 8,11003751 & 0,592874 & 0 & 0 \\
\hline $\begin{array}{l}\text { Czech } \\
\text { Republic }\end{array}$ & 2001 & 551,412456 & 8,37348181 & 0,939406 & 1 & 0 \\
\hline $\begin{array}{l}\text { Czech } \\
\text { Republic }\end{array}$ & 2002 & 830,427746 & 10,3823422 & 1 & 0 & 1 \\
\hline $\begin{array}{l}\text { Czech } \\
\text { Republic }\end{array}$ & 2003 & 206,072957 & 2,1175526 & 1 & 1 & 1 \\
\hline $\begin{array}{l}\text { Czech } \\
\text { Republic }\end{array}$ & 2004 & 487,320249 & 4,1810846 & 1 & 0 & 0 \\
\hline $\begin{array}{l}\text { Czech } \\
\text { Republic }\end{array}$ & 2005 & 1139,04878 & 8,56918642 & 1 & 0 & 1 \\
\hline $\begin{array}{l}\text { Czech } \\
\text { Republic }\end{array}$ & 2006 & 531,647245 & 3,51943537 & 1 & 0 & 0 \\
\hline $\begin{array}{l}\text { Czech } \\
\text { Republic }\end{array}$ & 2007 & 1010,25709 & 5,53114205 & 1 & 0 & 0 \\
\hline $\begin{array}{l}\text { Czech } \\
\text { Republic }\end{array}$ & 2008 & 619,583609 & 2,74271188 & 1 & 2 & 0 \\
\hline $\begin{array}{l}\text { Czech } \\
\text { Republic }\end{array}$ & 2009 & 279,104872 & 1,42264998 & 1 & 1 & 1 \\
\hline $\begin{array}{l}\text { Czech } \\
\text { Republic }\end{array}$ & 2010 & 581,841687 & 2,96623028 & 1 & 0 & 2 \\
\hline $\begin{array}{l}\text { Czech } \\
\text { Republic }\end{array}$ & 2011 & 218,409735 & 1,01956883 & 1 & 1 & 0 \\
\hline $\begin{array}{l}\text { Czech } \\
\text { Republic }\end{array}$ & 2012 & 748,974709 & 3,86169557 & 1 & 0 & 2 \\
\hline $\begin{array}{l}\text { Czech } \\
\text { Republic }\end{array}$ & 2013 & 340,035399 & 1,74290954 & 1 & 1 & 1 \\
\hline Denmark & 2000 & 6336,02403 & 20,6042406 & 1 & 0 & 0 \\
\hline Denmark & 2001 & 2151,86122 & 6,99220949 & 1 & 0 & 0 \\
\hline Denmark & 2002 & 1236,23828 & 3,71559989 & 1 & 0 & 1 \\
\hline Denmark & 2003 & 485,0473 & 1,19714611 & 1 & 0 & 0 \\
\hline Denmark & 2004 & $-1984,96835$ & $-4,26515205$ & 1 & 0 & 0 \\
\hline Denmark & 2005 & 1578,32961 & 3,23213389 & 1 & 0 & 1 \\
\hline Denmark & 2006 & 1709,29805 & 3,28671523 & 1 & 0 & 0 \\
\hline Denmark & 2007 & 1329,30349 & 2,27481314 & 1 & 0 & 0 \\
\hline Denmark & 2008 & $-147,573938$ & $-0,23003575$ & 1 & 1 & 0 \\
\hline
\end{tabular}


Heri Bezić, Tomislav Galović, Petar Mišević • The impact of terrorism on the FDI...

Zb. rad. Ekon. fak. Rij. • $2016 \cdot$ vol. $34 \cdot$ no. $2 \cdot 333-362$

\begin{tabular}{|c|c|c|c|c|c|c|}
\hline Country & Year & FDIpc & FDIgdp & ka_open & INCIDENTS & DISASTERS \\
\hline Denmark & 2009 & 70,9420179 & 0,12256338 & 1 & 0 & 0 \\
\hline Denmark & 2010 & $-1650,65947$ & $-2,86503671$ & 1 & 1 & 0 \\
\hline Denmark & 2011 & 2056,07204 & 3,35788926 & 1 & 0 & 0 \\
\hline Denmark & 2012 & 74,6339708 & 0,12986731 & 1 & 0 & 0 \\
\hline Denmark & 2013 & $-132,103515$ & $-0,22046333$ & 1 & 1 & 2 \\
\hline Estonia & 2000 & 286,420796 & 6,87695658 & 1 & 0 & 0 \\
\hline Estonia & 2001 & 397,544627 & 8,65108264 & 1 & 1 & 0 \\
\hline Estonia & 2002 & 214,241847 & 3,95047399 & 1 & 0 & 0 \\
\hline Estonia & 2003 & 692,819948 & 9,44789138 & 1 & 0 & 0 \\
\hline Estonia & 2004 & 718,595536 & 7,93787922 & 1 & 0 & 0 \\
\hline Estonia & 2005 & 2112,4062 & 19,9929246 & 1 & 0 & 0 \\
\hline Estonia & 2006 & 1011,76518 & 7,86443691 & 1 & 0 & 1 \\
\hline Estonia & 2007 & 1760,06776 & 10,3991296 & 1 & 0 & 0 \\
\hline Estonia & 2008 & 1399,02618 & 7,57425823 & 1 & 0 & 0 \\
\hline Estonia & 2009 & 1411,73464 & 9,3607778 & 1 & 0 & 0 \\
\hline Estonia & 2010 & 788,359738 & 5,25232472 & 1 & 0 & 0 \\
\hline Estonia & 2011 & 752,257902 & 4,27039368 & 1 & 1 & 0 \\
\hline Estonia & 2012 & 1215,78562 & 6,92523016 & 1 & 0 & 1 \\
\hline Estonia & 2013 & 429,53896 & 2,22234203 & 1 & 0 & 0 \\
\hline Finland & 2000 & 1706,57357 & 7,03685013 & 1 & 0 & 0 \\
\hline Finland & 2001 & 719,21591 & 2,88708676 & 1 & 0 & 0 \\
\hline Finland & 2002 & 1547,23474 & 5,76530519 & 1 & 0 & 0 \\
\hline Finland & 2003 & 636,643547 & 1,94017943 & 1 & 0 & 0 \\
\hline Finland & 2004 & 540,615119 & 1,43641033 & 1 & 0 & 0 \\
\hline Finland & 2005 & 905,419076 & 2,32360223 & 1 & 0 & 0 \\
\hline Finland & 2006 & 1452,53865 & 3,53360024 & 1 & 0 & 0 \\
\hline Finland & 2007 & 2352,68743 & 4,87565588 & 1 & 1 & 0 \\
\hline Finland & 2008 & $-215,106397$ & $-0,40316743$ & 1 & 1 & 0 \\
\hline Finland & 2009 & 134,285277 & 0,28535058 & 1 & 0 & 0 \\
\hline Finland & 2010 & 1370,94892 & 2,96966844 & 1 & 0 & 0 \\
\hline Finland & 2011 & 473,151079 & 0,93171025 & 1 & 0 & 0 \\
\hline Finland & 2012 & 768,788892 & 1,62562747 & 1 & 0 & 0 \\
\hline Finland & 2013 & $-951,825399$ & $-1,9320461$ & 1 & 0 & 0 \\
\hline France & 2000 & 449,994475 & 2,00554154 & 1 & 28 & 0 \\
\hline France & 2001 & 259,218211 & 1,15160902 & 1 & 21 & 0 \\
\hline France & 2002 & 347,003385 & 1,43118499 & 1 & 32 & 1 \\
\hline France & 2003 & 125,657873 & 0,42423277 & 1 & 34 & 1 \\
\hline France & 2004 & $-40,8403868$ & $-0,12092434$ & 1 & 11 & 0 \\
\hline
\end{tabular}


Heri Bezić, Tomislav Galović, Petar Mišević • The impact of terrorism on the FDI...

Zb. rad. Ekon. fak. Rij. • $2016 \cdot$ vol. $34 \cdot$ no. $2 \cdot 333-362$

\begin{tabular}{|c|c|c|c|c|c|c|}
\hline Country & Year & FDIpc & FDIgdp & ka_open & INCIDENTS & DISASTERS \\
\hline France & 2005 & 523,47419 & 1,505267 & 1 & 33 & 0 \\
\hline France & 2006 & 396,240441 & 1,0871859 & 1 & 34 & 1 \\
\hline France & 2007 & 987,427722 & 2,37929111 & 1 & 16 & 0 \\
\hline France & 2008 & 581,274062 & 1,28307522 & 1 & 13 & 0 \\
\hline France & 2009 & 472,539275 & 1,13863853 & 1 & 9 & 0 \\
\hline France & 2010 & 212,350222 & 0,52368754 & 1 & 3 & 2 \\
\hline France & 2011 & 480,993369 & 1,10298372 & 1 & 8 & 0 \\
\hline France & 2012 & 256,613895 & 0,63060108 & 1 & 65 & 0 \\
\hline France & 2013 & 644,557345 & 1,52479308 & 1 & 12 & 0 \\
\hline Germany & 2000 & 2374,21468 & 10,1826111 & 1 & 8 & 0 \\
\hline Germany & 2001 & 315,881252 & 1,35542376 & 1 & 8 & 0 \\
\hline Germany & 2002 & 639,56605 & 2,57764605 & 1 & 3 & 2 \\
\hline Germany & 2003 & 386,411848 & 1,29392686 & 1 & 2 & 2 \\
\hline Germany & 2004 & $-121,562724$ & $-0,36201589$ & 1 & 3 & 0 \\
\hline Germany & 2005 & 565,978793 & 1,6604869 & 1 & 3 & 0 \\
\hline Germany & 2006 & 664,601056 & 1,8560786 & 1 & 4 & 0 \\
\hline Germany & 2007 & 959,718187 & 2,33479648 & 1 & 3 & 1 \\
\hline Germany & 2008 & 97,4682052 & 0,21688641 & 1 & 3 & 0 \\
\hline Germany & 2009 & 286,179334 & 0,69753277 & 1 & 4 & 1 \\
\hline Germany & 2010 & 790,707032 & 1,92386508 & 1 & 1 & 0 \\
\hline Germany & 2011 & 814,480435 & 1,7993782 & 1 & 8 & 0 \\
\hline Germany & 2012 & 245,364739 & 0,57500243 & 1 & 5 & 0 \\
\hline Germany & 2013 & 219,913546 & 0,48770603 & 1 & 0 & 0 \\
\hline Greece & 2000 & 100,862355 & 0,8384297 & 0,752803 & 28 & 1 \\
\hline Greece & 2001 & 144,315533 & 1,16858679 & 0,752803 & 14 & 1 \\
\hline Greece & 2002 & 4,55784753 & 0,03290736 & 1 & 11 & 0 \\
\hline Greece & 2003 & 115,59687 & 0,63274564 & 1 & 12 & 0 \\
\hline Greece & 2004 & 190,448415 & 0,87693575 & 1 & 4 & 0 \\
\hline Greece & 2005 & 56,4490369 & 0,2516658 & 1 & 6 & 0 \\
\hline Greece & 2006 & 484,494933 & 1,95959212 & 1 & 23 & 0 \\
\hline Greece & 2007 & 190,776867 & 0,66254019 & 1 & 15 & 2 \\
\hline Greece & 2008 & 405,901033 & 1,26854583 & 1 & 53 & 0 \\
\hline Greece & 2009 & 219,528914 & 0,73865707 & 1 & 115 & 0 \\
\hline Greece & 2010 & 29,6952422 & 0,11011891 & 1 & 48 & 0 \\
\hline Greece & 2011 & 102,885793 & 0,39609741 & 1 & 11 & 0 \\
\hline Greece & 2012 & 156,429024 & 0,69741061 & 1 & 22 & 0 \\
\hline Greece & 2013 & 253,206555 & 1,16322343 & 1 & 53 & 0 \\
\hline Hungary & 2000 & 270,347346 & 5,86719889 & 0,411093 & 0 & 1 \\
\hline
\end{tabular}


Heri Bezić, Tomislav Galović, Petar Mišević • The impact of terrorism on the FDI...

\begin{tabular}{|c|c|c|c|c|c|c|}
\hline Country & Year & FDIpc & FDIgdp & ka_open & INCIDENTS & DISASTERS \\
\hline Hungary & 2001 & 386,033288 & 7,35256948 & 0,757624 & 1 & 0 \\
\hline Hungary & 2002 & 294,393333 & 4,44411659 & 0,818218 & 0 & 0 \\
\hline Hungary & 2003 & 210,742478 & 2,52235256 & 0,878812 & 0 & 1 \\
\hline Hungary & 2004 & 421,603722 & 4,13519201 & 0,939406 & 0 & 0 \\
\hline Hungary & 2005 & 763,568415 & 6,8897617 & 1 & 0 & 2 \\
\hline Hungary & 2006 & 676,543915 & 5,96781966 & 1 & 0 & 1 \\
\hline Hungary & 2007 & 392,696467 & 2,85093932 & 1 & 0 & 1 \\
\hline Hungary & 2008 & 629,81777 & 4,04089309 & 1 & 2 & 1 \\
\hline Hungary & 2009 & 198,913072 & 1,54245405 & 1 & 1 & 0 \\
\hline Hungary & 2010 & 218,960701 & 1,69220575 & 1 & 0 & 0 \\
\hline Hungary & 2011 & 630,249947 & 4,51817173 & 1 & 0 & 0 \\
\hline Hungary & 2012 & 1440,92809 & 11,3345143 & 1 & 0 & 1 \\
\hline Hungary & 2013 & 311,127917 & 2,32136827 & 1 & 0 & 0 \\
\hline Ireland & 2000 & 6777,38998 & 25,9566615 & 1 & 0 & 2 \\
\hline Ireland & 2001 & 2496,46205 & 8,89858827 & 1 & 2 & 0 \\
\hline Ireland & 2002 & 7450,38817 & 23,0494743 & 1 & 0 & 0 \\
\hline Ireland & 2003 & 5680,19684 & 13,93607 & 1 & 1 & 0 \\
\hline Ireland & 2004 & $-2596,22073$ & $-5,49495079$ & 1 & 0 & 0 \\
\hline Ireland & 2005 & $-7621,28063$ & $-15,0644683$ & 1 & 0 & 0 \\
\hline Ireland & 2006 & $-1311,44591$ & $-2,40423548$ & 1 & 1 & 0 \\
\hline Ireland & 2007 & 5758,52713 & 9,17513565 & 1 & 1 & 0 \\
\hline Ireland & 2008 & $-3780,84122$ & $-6,01059306$ & 1 & 5 & 0 \\
\hline Ireland & 2009 & 5830,58256 & 11,0109861 & 1 & 0 & 0 \\
\hline Ireland & 2010 & 9581,08267 & 19,5958224 & 1 & 4 & 0 \\
\hline Ireland & 2011 & 5205,72968 & 9,90224972 & 1 & 4 & 1 \\
\hline Ireland & 2012 & 9879,295 & 20,3664044 & 1 & 29 & 0 \\
\hline Ireland & 2013 & 8003,45024 & 15,9573472 & 1 & 26 & 0 \\
\hline Italy & 2000 & 234,702782 & 1,17095429 & 1 & 7 & 1 \\
\hline Italy & 2001 & 259,973774 & 1,27888614 & 1 & 11 & 0 \\
\hline Italy & 2002 & 296,59915 & 1,34597674 & 1 & 7 & 1 \\
\hline Italy & 2003 & 335,66697 & 1,23700902 & 1 & 15 & 1 \\
\hline Italy & 2004 & 345,407134 & 1,118598 & 1 & 3 & 0 \\
\hline Italy & 2005 & 396,975685 & 1,25663492 & 1 & 6 & 0 \\
\hline Italy & 2006 & 720,754397 & 2,19101832 & 1 & 4 & 0 \\
\hline Italy & 2007 & 737,143412 & 1,98955962 & 1 & 0 & 0 \\
\hline Italy & 2008 & $-180,969194$ & $-0,45298839$ & 1 & 2 & 0 \\
\hline Italy & 2009 & 333,385841 & 0,91837202 & 1 & 4 & 2 \\
\hline Italy & 2010 & 151,684282 & 0,43158905 & 1 & 10 & 0 \\
\hline
\end{tabular}


Heri Bezić, Tomislav Galović, Petar Mišević • The impact of terrorism on the FDI...

Zb. rad. Ekon. fak. Rij. • 2016 • vol. $34 \cdot$ no. $2 \cdot 333-362$

\begin{tabular}{|c|c|c|c|c|c|c|}
\hline Country & Year & FDIpc & FDIgdp & ka_open & INCIDENTS & DISASTERS \\
\hline Italy & 2011 & 565,193324 & 1,50659934 & 1 & 3 & 0 \\
\hline Italy & 2012 & 1,51943248 & 0,00442259 & 1 & 10 & 1 \\
\hline Italy & 2013 & 409,972828 & 1,16327222 & 1 & 7 & 0 \\
\hline Latvia & 2000 & 138,305844 & 3,32240713 & 0,939406 & 3 & 0 \\
\hline Latvia & 2001 & 45,0225946 & 1,0116189 & 0,939406 & 0 & 1 \\
\hline Latvia & 2002 & 90,5692007 & 1,82160806 & 0,939406 & 0 & 0 \\
\hline Latvia & 2003 & 122,345228 & 2,17244149 & 1 & 0 & 1 \\
\hline Latvia & 2004 & 268,942891 & 3,97702171 & 1 & 0 & 0 \\
\hline Latvia & 2005 & 317,025545 & 4,13185381 & 1 & 0 & 0 \\
\hline Latvia & 2006 & 757,211265 & 7,69584337 & 1 & 0 & 1 \\
\hline Latvia & 2007 & 1072,21689 & 7,50868933 & 1 & 1 & 0 \\
\hline Latvia & 2008 & 591,181163 & 3,54388159 & 1 & 0 & 0 \\
\hline Latvia & 2009 & 44,4391539 & 0,35886348 & 1 & 0 & 0 \\
\hline Latvia & 2010 & 181,487887 & 1,58962902 & 1 & 0 & 0 \\
\hline Latvia & 2011 & 700,875691 & 5,13144649 & 1 & 0 & 0 \\
\hline Latvia & 2012 & 538,281309 & 3,88450043 & 1 & 0 & 1 \\
\hline Latvia & 2013 & 440,476314 & 2,92404055 & 1 & 0 & 0 \\
\hline Lithuania & 2000 & 108,29737 & 3,29436285 & 1 & 0 & 0 \\
\hline Lithuania & 2001 & 128,787393 & 3,64825771 & 1 & 0 & 1 \\
\hline Lithuania & 2002 & 211,891277 & 5,09194937 & 1 & 0 & 0 \\
\hline Lithuania & 2003 & 53,4007096 & 0,964854 & 1 & 0 & 0 \\
\hline Lithuania & 2004 & 232,113829 & 3,4163726 & 1 & 0 & 0 \\
\hline Lithuania & 2005 & 312,79394 & 3,93278564 & 1 & 0 & 0 \\
\hline Lithuania & 2006 & 560,938313 & 6,01412749 & 1 & 0 & 0 \\
\hline Lithuania & 2007 & 631,648247 & 5,07156566 & 1 & 0 & 0 \\
\hline Lithuania & 2008 & 624,984383 & 4,10166317 & 0,939406 & 0 & 0 \\
\hline Lithuania & 2009 & $-4,42287572$ & $-0,03664499$ & 0,878812 & 0 & 0 \\
\hline Lithuania & 2010 & 260,586815 & 2,15552428 & 0,818218 & 0 & 2 \\
\hline Lithuania & 2011 & 475,691312 & 3,32987451 & 0,757624 & 0 & 0 \\
\hline Lithuania & 2012 & 231,282955 & 1,63531156 & 0,69703 & 0 & 2 \\
\hline Lithuania & 2013 & 155,451595 & 1,01068177 & 0,69703 & 0 & 0 \\
\hline Malta & 2000 & 1427,03226 & 14,3475982 & 0,163896 & 0 & 0 \\
\hline Malta & 2001 & 574,976571 & 5,78473152 & 0,163896 & 0 & 0 \\
\hline Malta & 2002 & $-1019,93679$ & $-9,37236194$ & 0,163896 & 0 & 0 \\
\hline Malta & 2003 & 2330,76256 & 17,7221506 & 0,163896 & 0 & 0 \\
\hline Malta & 2004 & 957,087173 & 6,5427102 & 0,510427 & 0 & 0 \\
\hline Malta & 2005 & 1629,637 & 10,5721092 & 0,818218 & 0 & 0 \\
\hline Malta & 2006 & 4425,50945 & 27,1800198 & 0,878812 & 0 & 0 \\
\hline
\end{tabular}


Heri Bezić, Tomislav Galović, Petar Mišević • The impact of terrorism on the FDI...

\begin{tabular}{|c|c|c|c|c|c|c|}
\hline Country & Year & FDIpc & FDIgdp & ka_open & INCIDENTS & DISASTERS \\
\hline Malta & 2007 & 1821,15436 & 9,61378957 & 0,939406 & 0 & 0 \\
\hline Malta & 2008 & 1016,56505 & 4,76488287 & 1 & 0 & 0 \\
\hline Malta & 2009 & $-20443,3173$ & $-101,374556$ & 1 & 0 & 0 \\
\hline Malta & 2010 & 2186,07197 & 10,6230041 & 1 & 0 & 0 \\
\hline Malta & 2011 & 36378,7589 & 161,833043 & 1 & 0 & 0 \\
\hline Malta & 2012 & 28195,9779 & 130,760614 & 1 & 0 & 0 \\
\hline Malta & 2013 & 22319,6346 & 96,0261413 & 1 & 0 & 0 \\
\hline Netherlands & 2000 & 4026,20025 & 15,4464227 & 1 & 1 & 0 \\
\hline Netherlands & 2001 & 3255,59892 & 12,1870517 & 1 & 1 & 0 \\
\hline Netherlands & 2002 & 1560,75818 & 5,39037022 & 1 & 2 & 1 \\
\hline Netherlands & 2003 & 2034,20302 & 5,7487994 & 1 & 3 & 1 \\
\hline Netherlands & 2004 & 767,655832 & 1,92741168 & 1 & 1 & 0 \\
\hline Netherlands & 2005 & 2395,20296 & 5,80750366 & 1 & 0 & 0 \\
\hline Netherlands & 2006 & 853,559479 & 1,94303536 & 1 & 0 & 1 \\
\hline Netherlands & 2007 & 7275,86195 & 14,3595047 & 1 & 0 & 1 \\
\hline Netherlands & 2008 & 350,004262 & 0,62024749 & 1 & 1 & 0 \\
\hline Netherlands & 2009 & 2339,92169 & 4,5163837 & 1 & 1 & 0 \\
\hline Netherlands & 2010 & $-432,40241$ & $-0,85898584$ & 1 & 1 & 0 \\
\hline Netherlands & 2011 & 1462,15214 & 2,72652644 & 1 & 2 & 0 \\
\hline Netherlands & 2012 & 1056,30069 & 2,14484112 & 1 & 0 & 0 \\
\hline Netherlands & 2013 & 1911,74567 & 3,753709 & 1 & 0 & 1 \\
\hline Poland & 2000 & 246,283209 & 5,50080626 & 0,163896 & 0 & 1 \\
\hline Poland & 2001 & 145,616402 & 2,92259012 & 0,163896 & 1 & 1 \\
\hline Poland & 2002 & 105,278204 & 2,02845141 & 0,449833 & 0 & 1 \\
\hline Poland & 2003 & 104,111415 & 1,83082366 & 0,449833 & 0 & 0 \\
\hline Poland & 2004 & 325,438125 & 4,90680928 & 0,449833 & 0 & 0 \\
\hline Poland & 2005 & 254,373356 & 3,19260855 & 0,449833 & 0 & 1 \\
\hline Poland & 2006 & 481,260078 & 5,35483817 & 0,449833 & 0 & 0 \\
\hline Poland & 2007 & 566,720381 & 5,0477664 & 0,449833 & 0 & 0 \\
\hline Poland & 2008 & 362,988282 & 2,61468408 & 0,449833 & 0 & 1 \\
\hline Poland & 2009 & 311,269505 & 2,7237805 & 0,449833 & 0 & 1 \\
\hline Poland & 2010 & 334,976119 & 2,68428685 & 0,449833 & 0 & 1 \\
\hline Poland & 2011 & 477,912825 & 3,48208588 & 0,449833 & 0 & 0 \\
\hline Poland & 2012 & 186,323181 & 1,43482168 & 0,449833 & 0 & 2 \\
\hline Poland & 2013 & 3,12944319 & 0,02274295 & 0,449833 & 0 & 0 \\
\hline Portugal & 2000 & 636,489638 & 5,54230601 & 1 & 0 & 1 \\
\hline Portugal & 2001 & 598,576149 & 5,09742872 & 1 & 0 & 1 \\
\hline Portugal & 2002 & 157,45604 & 1,2193968 & 1 & 0 & 0 \\
\hline
\end{tabular}


Heri Bezić, Tomislav Galović, Petar Mišević • The impact of terrorism on the FDI...

Zb. rad. Ekon. fak. Rij. • 2016 • vol. $34 \cdot$ no. $2 \cdot 333-362$

\begin{tabular}{|c|c|c|c|c|c|c|}
\hline Country & Year & FDIpc & FDIgdp & ka_open & INCIDENTS & DISASTERS \\
\hline Portugal & 2003 & 764,807301 & 4,83993131 & 1 & 0 & 2 \\
\hline Portugal & 2004 & 171,078226 & 0,94747315 & 1 & 0 & 0 \\
\hline Portugal & 2005 & 329,541415 & 1,75560312 & 1 & 0 & 1 \\
\hline Portugal & 2006 & 1005,42831 & 5,07963565 & 1 & 0 & 1 \\
\hline Portugal & 2007 & 272,362821 & 1,19714829 & 1 & 0 & 0 \\
\hline Portugal & 2008 & 335,745472 & 1,35441033 & 1 & 0 & 0 \\
\hline Portugal & 2009 & 152,289328 & 0,66110714 & 1 & 0 & 0 \\
\hline Portugal & 2010 & 228,899795 & 1,01719108 & 1 & 0 & 1 \\
\hline Portugal & 2011 & 700,926065 & 3,03319805 & 1 & 2 & 0 \\
\hline Portugal & 2012 & 777,245314 & 3,78061812 & 1 & 0 & 0 \\
\hline Portugal & 2013 & 210,561739 & 0,98259481 & 1 & 0 & 1 \\
\hline Romania & 2000 & 47,2010256 & 2,82259945 & 0,163896 & 0 & 0 \\
\hline Romania & 2001 & 51,9016897 & 2,84384362 & 0,163896 & 0 & 0 \\
\hline Romania & 2002 & 51,2662722 & 2,4703367 & 0,449833 & 0 & 0 \\
\hline Romania & 2003 & 98,9255176 & 3,66859751 & 0,510427 & 0 & 0 \\
\hline Romania & 2004 & 290,438847 & 8,44372431 & 0,818218 & 0 & 0 \\
\hline Romania & 2005 & 278,217671 & 6,17086467 & 0,878812 & 0 & 1 \\
\hline Romania & 2006 & 492,087769 & 8,78959488 & 0,939406 & 0 & 2 \\
\hline Romania & 2007 & 442,080201 & 5,67377774 & 1 & 0 & 1 \\
\hline Romania & 2008 & 614,229894 & 6,48054937 & 1 & 1 & 0 \\
\hline Romania & 2009 & 212,904778 & 2,78664716 & 1 & 0 & 1 \\
\hline Romania & 2010 & 139,104772 & 1,81016094 & 1 & 0 & 1 \\
\hline Romania & 2011 & 108,346576 & 1,27475888 & 1 & 0 & 0 \\
\hline Romania & 2012 & 147,027659 & 1,85915038 & 1 & 0 & 1 \\
\hline Romania & 2013 & 165,979489 & 1,8748765 & 1 & 0 & 0 \\
\hline Slovakia & 2000 & 504,89488 & 13,1566138 & 0,163896 & 1 & 1 \\
\hline Slovakia & 2001 & 422,169723 & 10,6429966 & 0,163896 & 0 & 0 \\
\hline Slovakia & 2002 & 1088,52515 & 23,628819 & 0,163896 & 0 & 0 \\
\hline Slovakia & 2003 & 552,334211 & 8,75769705 & 0,510427 & 0 & 0 \\
\hline Slovakia & 2004 & 747,724405 & 9,34305129 & 0,571021 & 0 & 1 \\
\hline Slovakia & 2005 & 576,767914 & 6,35287939 & 0,631615 & 0 & 0 \\
\hline Slovakia & 2006 & 1075,16408 & 10,1868145 & 0,692209 & 0 & 1 \\
\hline Slovakia & 2007 & 743,147386 & 5,23901778 & 0,752803 & 0 & 1 \\
\hline Slovakia & 2008 & 898,916612 & 5,0645291 & 0,752803 & 0 & 0 \\
\hline Slovakia & 2009 & $-1,12056296$ & $-0,00685906$ & 0,752803 & 0 & 0 \\
\hline Slovakia & 2010 & 325,716621 & 1,98834729 & 0,752803 & 0 & 3 \\
\hline Slovakia & 2011 & 641,750658 & 3,57964944 & 0,752803 & 0 & 0 \\
\hline Slovakia & 2012 & 547,52501 & 3,21484859 & 0,752803 & 0 & 1 \\
\hline
\end{tabular}


Heri Bezić, Tomislav Galović, Petar Mišević • The impact of terrorism on the FDI...

\begin{tabular}{|c|c|c|c|c|c|c|}
\hline Country & Year & FDIpc & FDIgdp & ka_open & INCIDENTS & DISASTERS \\
\hline Slovakia & 2013 & 108,438617 & 0,60484951 & 0,752803 & 0 & 0 \\
\hline Slovenia & 2000 & 67,0077364 & 0,65530912 & 0,69703 & 1 & 0 \\
\hline Slovenia & 2001 & 180,191259 & 1,71743967 & 0,69703 & 0 & 0 \\
\hline Slovenia & 2002 & 788,745451 & 6,66169256 & 0,69703 & 0 & 0 \\
\hline Slovenia & 2003 & 136,177674 & 0,91311066 & 0,757624 & 0 & 1 \\
\hline Slovenia & 2004 & 338,646195 & 1,9595161 & 0,818218 & 0 & 1 \\
\hline Slovenia & 2005 & 280,77453 & 1,54532529 & 0,878812 & 0 & 0 \\
\hline Slovenia & 2006 & 351,549895 & 1,78418263 & 0,939406 & 0 & 0 \\
\hline Slovenia & 2007 & 374,868016 & 1,57401114 & 1 & 0 & 1 \\
\hline Slovenia & 2008 & 599,472336 & 2,19170245 & 0,939406 & 0 & 0 \\
\hline Slovenia & 2009 & $-232,767531$ & $-0,94708968$ & 0,878812 & 0 & 0 \\
\hline Slovenia & 2010 & 51,2938504 & 0,21965644 & 0,818218 & 0 & 0 \\
\hline Slovenia & 2011 & 527,37204 & 2,12170393 & 0,757624 & 0 & 0 \\
\hline Slovenia & 2012 & 164,108633 & 0,73348478 & 0,69703 & 0 & 0 \\
\hline Slovenia & 2013 & $-69,2569015$ & $-0,29902172$ & 0,69703 & 0 & 0 \\
\hline Spain & 2000 & 982,431104 & 6,6467853 & 1 & 112 & 1 \\
\hline Spain & 2001 & 697,017821 & 4,53825551 & 1 & 78 & 0 \\
\hline Spain & 2002 & 948,625471 & 5,56208105 & 1 & 40 & 0 \\
\hline Spain & 2003 & 614,513198 & 2,84724104 & 1 & 21 & 1 \\
\hline Spain & 2004 & 579,735651 & 2,31494374 & 1 & 31 & 1 \\
\hline Spain & 2005 & 576,668331 & 2,16204227 & 1 & 24 & 0 \\
\hline Spain & 2006 & 699,442779 & 2,43595915 & 1 & 23 & 1 \\
\hline Spain & 2007 & 1438,83928 & 4,34434553 & 1 & 11 & 0 \\
\hline Spain & 2008 & 1701,74095 & 4,70887947 & 1 & 37 & 0 \\
\hline Spain & 2009 & 227,445422 & 0,69424323 & 1 & 21 & 1 \\
\hline Spain & 2010 & 863,377 & 2,7851952 & 1 & 3 & 0 \\
\hline Spain & 2011 & 610,120293 & 1,89878513 & 1 & 0 & 0 \\
\hline Spain & 2012 & 549,603361 & 1,89539243 & 1 & 1 & 0 \\
\hline Spain & 2013 & 889,324494 & 2,99584307 & 1 & 5 & 0 \\
\hline Sweden & 2000 & 2641,12452 & 9,01952974 & 1 & 0 & 0 \\
\hline Sweden & 2001 & 1227,9264 & 4,54923092 & 1 & 0 & 1 \\
\hline Sweden & 2002 & 1377,26631 & 4,6501876 & 1 & 0 & 0 \\
\hline Sweden & 2003 & 603,441562 & 1,62962354 & 1 & 0 & 0 \\
\hline Sweden & 2004 & 1360,0644 & 3,20013784 & 1 & 3 & 1 \\
\hline Sweden & 2005 & 1287,41594 & 2,98825029 & 1 & 1 & 0 \\
\hline Sweden & 2006 & 3028,93358 & 6,5547871 & 1 & 0 & 0 \\
\hline Sweden & 2007 & 3149,37323 & 5,91318245 & 1 & 1 & 0 \\
\hline Sweden & 2008 & 3994,55048 & 7,17711688 & 1 & 1 & 0 \\
\hline
\end{tabular}


Heri Bezić, Tomislav Galović, Petar Mišević • The impact of terrorism on the FDI...

Zb. rad. Ekon. fak. Rij. • $2016 \cdot$ vol. $34 \cdot$ no. $2 \cdot 333-362$

\begin{tabular}{|c|c|c|c|c|c|c|}
\hline Country & Year & FDIpc & FDIgdp & ka_open & INCIDENTS & DISASTERS \\
\hline Sweden & 2009 & 1084,11967 & 2,34919911 & 1 & 3 & 0 \\
\hline Sweden & 2010 & 14,9734131 & 0,02876565 & 1 & 1 & 0 \\
\hline Sweden & 2011 & 1367,71163 & 2,29501643 & 1 & 2 & 0 \\
\hline Sweden & 2012 & 1717,3672 & 3,0033091 & 1 & 0 & 1 \\
\hline Sweden & 2013 & 373,09596 & 0,6160193 & 1 & 6 & 1 \\
\hline $\begin{array}{l}\text { United } \\
\text { Kingdom }\end{array}$ & 2000 & 2059,88473 & 7,87152273 & 1 & 5 & 1 \\
\hline $\begin{array}{l}\text { United } \\
\text { Kingdom }\end{array}$ & 2001 & 621,682245 & 2,4153175 & 1 & 0 & 0 \\
\hline $\begin{array}{l}\text { United } \\
\text { Kingdom }\end{array}$ & 2002 & 354,306753 & 1,26247522 & 1 & 0 & 0 \\
\hline $\begin{array}{l}\text { United } \\
\text { Kingdom }\end{array}$ & 2003 & 284,21327 & 0,87625279 & 1 & 0 & 1 \\
\hline $\begin{array}{l}\text { United } \\
\text { Kingdom }\end{array}$ & 2004 & 1024,28469 & 2,68389432 & 1 & 1 & 0 \\
\hline $\begin{array}{l}\text { United } \\
\text { Kingdom }\end{array}$ & 2005 & 3037,08016 & 7,62079668 & 1 & 0 & 0 \\
\hline $\begin{array}{l}\text { United } \\
\text { Kingdom }\end{array}$ & 2006 & 2444,06719 & 5,75881265 & 1 & 2 & 0 \\
\hline $\begin{array}{l}\text { United } \\
\text { Kingdom }\end{array}$ & 2007 & 2967,89393 & 6,13042788 & 1 & 0 & 1 \\
\hline $\begin{array}{l}\text { United } \\
\text { Kingdom }\end{array}$ & 2008 & 1516,30954 & 3,34416668 & 1 & 5 & 0 \\
\hline $\begin{array}{l}\text { United } \\
\text { Kingdom }\end{array}$ & 2009 & 1462,49574 & 3,92350702 & 1 & 4 & 0 \\
\hline $\begin{array}{l}\text { United } \\
\text { Kingdom }\end{array}$ & 2010 & 946,147581 & 2,44833658 & 1 & 2 & 0 \\
\hline $\begin{array}{l}\text { United } \\
\text { Kingdom }\end{array}$ & 2011 & 667,013416 & 1,6128679 & 1 & 0 & 0 \\
\hline $\begin{array}{l}\text { United } \\
\text { Kingdom }\end{array}$ & 2012 & 942,01306 & 2,27059095 & 1 & 2 & 0 \\
\hline $\begin{array}{l}\text { United } \\
\text { Kingdom }\end{array}$ & 2013 & 752,163391 & 1,77995356 & 1 & 3 & 1 \\
\hline Switzerland & 2000 & 2674,84635 & 7,02399318 & 1 & 0 & 1 \\
\hline Switzerland & 2001 & 1224,15285 & 3,15021977 & 1 & 0 & 0 \\
\hline Switzerland & 2002 & 862,717208 & 2,06591334 & 1 & 0 & 3 \\
\hline Switzerland & 2003 & 2253,58129 & 4,64799745 & 1 & 1 & 1 \\
\hline Switzerland & 2004 & 126,342674 & 0,23483477 & 1 & 0 & 0 \\
\hline Switzerland & 2005 & $-127,790314$ & $-0,23131906$ & 1 & 0 & 1 \\
\hline Switzerland & 2006 & 5815,72495 & 10,0923068 & 1 & 1 & 1 \\
\hline Switzerland & 2007 & 4267,77375 & 6,72896922 & 1 & 0 & 1 \\
\hline Switzerland & 2008 & 1978,53053 & 2,7328963 & 1 & 3 & 0 \\
\hline Switzerland & 2009 & 3714,1492 & 5,31071989 & 1 & 0 & 0 \\
\hline
\end{tabular}


Heri Bezić, Tomislav Galović, Petar Mišević • The impact of terrorism on the FDI... Zb. rad. Ekon. fak. Rij. • $2016 \cdot$ vol. $34 \cdot$ no. $2 \cdot 333-362$

\begin{tabular}{|c|c|c|c|c|c|c|}
\hline Country & Year & FDIpc & FDIgdp & ka_open & INCIDENTS & DISASTERS \\
\hline Switzerland & 2010 & 3653,92795 & 4,90271748 & 1 & 0 & 0 \\
\hline Switzerland & 2011 & 3560,18622 & 4,03253412 & 1 & 0 & 0 \\
\hline Switzerland & 2012 & 1990,13598 & 2,38075322 & 1 & 0 & 1 \\
\hline Switzerland & 2013 & $-2779,52821$ & $-3,26375492$ & 1 & 0 & 0 \\
\hline Norway & 2000 & 1578,61196 & 4,13884152 & 1 & 0 & 0 \\
\hline Norway & 2001 & 470,158635 & 1,21987676 & 1 & 1 & 0 \\
\hline Norway & 2002 & 174,380763 & 0,40482477 & 1 & 0 & 0 \\
\hline Norway & 2003 & 761,106354 & 1,51721358 & 1 & 1 & 0 \\
\hline Norway & 2004 & 554,382277 & 0,96224418 & 1 & 0 & 0 \\
\hline Norway & 2005 & 471,526175 & 0,70630516 & 1 & 0 & 0 \\
\hline Norway & 2006 & 2254,45915 & 3,04729244 & 1 & 1 & 0 \\
\hline Norway & 2007 & 1692,05728 & 1,99266992 & 1 & 0 & 0 \\
\hline Norway & 2008 & 2145,4602 & 2,21906209 & 1 & 0 & 0 \\
\hline Norway & 2009 & 3441,42639 & 4,30699846 & 1 & 0 & 0 \\
\hline Norway & 2010 & 3484,56092 & 3,97731287 & 1 & 1 & 0 \\
\hline Norway & 2011 & 3084,68949 & 3,06127455 & 1 & 3 & 1 \\
\hline Norway & 2012 & 3759,48289 & 3,6833841 & 1 & 0 & 0 \\
\hline Norway & 2013 & 2863,79807 & 2,76466281 & 1 & 0 & 0 \\
\hline Iceland & 2000 & 608,877598 & 1,91358358 & 0,878812 & 0 & 0 \\
\hline Iceland & 2001 & 611,873029 & 2,13333441 & 0,878812 & 0 & 0 \\
\hline Iceland & 2002 & 304,367995 & 0,950815 & 0,818218 & 0 & 0 \\
\hline Iceland & 2003 & 1146,00558 & 2,933981 & 0,757624 & 0 & 0 \\
\hline Iceland & 2004 & 2512,33099 & 5,3617295 & 0,69703 & 0 & 0 \\
\hline Iceland & 2005 & 10381,6556 & 18,3391554 & 0,69703 & 0 & 0 \\
\hline Iceland & 2006 & 12779,6838 & 22,4709224 & 0,69703 & 0 & 0 \\
\hline Iceland & 2007 & 22378,2399 & 31,8202233 & 0,69703 & 0 & 0 \\
\hline Iceland & 2008 & 2964,8424 & 5,21218046 & 0,163896 & 0 & 0 \\
\hline Iceland & 2009 & 273,570105 & 0,66943544 & 0,163896 & 0 & 0 \\
\hline Iceland & 2010 & 772,645978 & 1,85305191 & 0,163896 & 0 & 0 \\
\hline Iceland & 2011 & 3441,18713 & 7,55663988 & 0,163896 & 0 & 0 \\
\hline Iceland & 2012 & 3145,82121 & 7,2279994 & 0,163896 & 1 & 0 \\
\hline Iceland & 2013 & 1204,2544 & 2,58866586 & 0,163896 & 0 & 0 \\
\hline
\end{tabular}

Source: Authors' calculations 